\title{
Organizational Business Excellence

\section{THE INFLUENCE OF SOCIAL MEDIA BRANDING ON CUSTOMER ENGAGEMENT FOR JAKARTA SUSTAINABLE TRANSPORT}

\author{
Yulianne Safitri ${ }^{1}$, Lidya Wati Evelina ${ }^{2 *}$ and Naufal Egha Syahputra ${ }^{3}$ \\ ${ }_{1,2,3}$ Marketing Communication Program, Communication Departement, Faculty of Economics and \\ Communications, Bina Nusantara, Jakarta, Indonesia 11480.
}

\begin{abstract}
The research aimed to understand the relationship and influence of Instagram @mrtjkt social media branding on customer engagement as an effort to increase the use of MRT as sustainable green transportation to reduce traffic congestion and pollution in Jakarta. The quantitative research approach with a survey method was carried out to 100 respondents from the total population on Instagram Followers $@$ @ mrtjkt. The quantitative analysis was implemented using correlation test, coefficient determination test, and simple regression analysis. The data validity techniques were the validity test, reliability test and normality test. Research result shows that $H_{0}$ is rejected and $H_{1}$ is accepted since it shows relationships and influences between Instagram social media branding on MRT Jakarta customer engagement.
\end{abstract}

Keywords: customer engagement, Instagram, social media branding, sustainable transport

\section{INTRODUCTION}

The growth rate of transportation in Jakarta reaches $6.48 \%$ per year (data for the 20122017 period) is predicted to continue to increase every year (Kemal \& Ernungtyas, 2020). Indonesia is the second worst country with traffic congestion in the world. The average Indonesian spends 47 hours on the highway per year (Nurcahyo, lqbal, \& Habiburrahman, 2020).

The imbalance between the increase in the number of vehicles and roads is one of the causes of congestion in Jakarta (Setia, Nelwa, Marina \& Hidayat, 2019).

The high congestion causes wasteful use of fuel and pollution so that the need for environmentally friendly transportation is

\section{ARTICLE INFO}

Article history:

Received: 14 August 2020

Accepted: 06 October 2020

Email Addresses:

lidiaevelina@binus.ac.id (Lidya Wati Evelina)

*Corresponding author important (Chasanah \& Wijaya, 2020). One of the solutions offered to reduce congestion and pollution in Jakarta is by maximizing the use of mass public transportation such as BRT, MRT and LRT and encouraging transit-oriented development (TOD) around public transport stations (Budiati, Grigolo, Brussel, \& Rachmat, 2018).

The Jakarta Mass Rapid Transit (Moda Raya Terpadu Jakarta) or commonly referred to as the MRT Jakarta, is a transit transportation system that uses electric trains. MRT Jakarta began operating in Jakarta in 2019, as an effort to create a Green Environment in Jakarta by reducing road congestion and pollution (Jakarta MRT, n.d.).

One way of socializing this is through branding on social media. The purpose of branding or the process of building this brand is to form and communicate the brand effectively and differently from competitors, which in turn encourages consumers to have a strong brand awareness and positive brand 
Safitri, Yulianne, Evelina, Lidya W. and Syahputra, Naufal E.

image, and leads to brand strength or brand equity (Jokinen, 2016; Kompella, 2014).

In Indonesia Instagram is in the 4th position of the social media platform most actively accessed by users ("Hootsuite", 2019). Instagram, which was launched in 2010, is a photo sharing application that allows users to take photos, apply digital filters, and share them on various social networking services, including Instagram itself (Atmoko, 2012).

Based on observations on the Instagram @mrtjkt social media account, the content is in the form of general information about MRT Jakarta which is useful for the public and an Instagram story which is updated every 24 hours. The relationship between social media branding and customer engagement is so that companies can invite customers to engage and interact in social media, which indirectly creates a cognitive relationship so that consumers can become marketers for the company (VanAuken, 2015); (Barger, 2016); (Yoong \& Lian, 2019).

Based on this background, this study wanted to find out how much influence the social media content of Instagram @mrtjkt branding on the customer engagement of MRT Jakarta users.

\section{LITERATURE REVIEW}

\section{Content in social media branding}

Content is the basic ingredient of culture contained in social media. Content can be in the form of written text, photos, videos, sound, or other types that are spread on social media. Basically, content is the basic ingredient of culture contained in social media (Nasrullah, 2015). Are all forms of content or content in a media in the technology world today such as blogs, wikis, discussion forums, chats, tweets, podcasting, pins, digital images, videos, audio files, advertisements to various other forms of media content formed through the creation of system users or online services which are often done through a social media site (Moens, Li, \& Chua, 2014).

Branding in the digital realm highlights people's perceptions of a brand through digital content that occurs on the internet
(Ramkumar, Kumar, Janakiraman \& Bezawada, 2016). Digital branding is a branding technique that uses a combination of internet branding and digital marketing to develop brands for various digital venues including internet-based relationships, device-based applications or media content (Rowles, 2014).

Digital branding is more focused on content that is made to attract the attention of its audience. So that it can have an impact on the engagement generated by the audience on the digital assets owned by a brand (Ramkumar et al., 2016).

\section{Social media branding dimension and indicator}

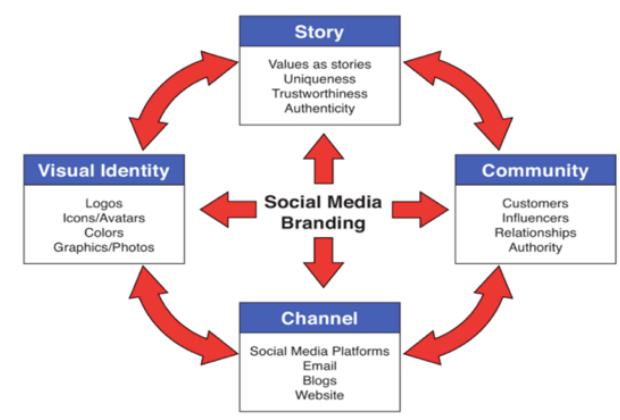

Figure 1. Social Media Branding Model

(Rowles, 2014)

As seen in Figure 1, dimensions and indicators of Social Media Branding (Rowles, 2014) used in the research are:

1. Story: The story in the message content describes a brand in the story. The following are indicators of the story dimensions: (a) Value as stories, the value of the message content describes a brand that is told. The content of the content must reflect a positive side so that customers (followers) know the value of the brand itself; (b) Uniqueness, the uniqueness of a brand will be an added value for customers (followers) of various competing brands; (c) Trustworthiness, this involves communication from customers to brands to create honest and trustworthy credibility. Looks like a testimonial for example. 
2. Community: The community of a brand, reflects the value of the brand: (a) Customers, customers will provide feedback, rating, focus, and ideas if they are interested in the brand, which will help create a better brand; (b) Influencers, if a brand or a company has not had a high influencer value, the company can use various influencers to gain higher influence and strengthen brand awareness of the company. (In this study the influencers indicator was not used because the social media object that wanted to be researched did not use KOL/Influencer); (c) Relationship, a strong relationship with vendors, colleagues, and customers will help the brand/company in creating better customer engagement and brand ambassadors.

3. Channel: The channelling process in choosing the right platform: (a) Social media platforms, the brand/company must ensure its presence on various social media platforms and choose the right social media platform to convince the audience who will become potential customers; (b) Website, this is the center of the brand/company. Everything that is considered important must be covered practically on the website of the brand / company, because all branding of the brand / company will be displayed at any time on the website.

4. Visual Identity: Visual identity will be something that comes to mind for customers when thinking about a company's brand: (a) Logos, this reflects the symbol or symbol of the brand or company. It looks like a small thing but has a huge effect; (b) Color / Fonts, when sending messages, these are two things that customers will remember, the color scheme and font of the message. This visual effect will create a familiar feeling between the customer and the company; (c) Graphics / Photos, visualizations and images can communicate the brand or company in a different way that is done by text or writing that does not have graphic visualization (Diamond, 2013; Kriyantono, 2014).

\section{Customer engagement}

Customer Engagement aims to develop a customer portfolio and maintain relationships with customers (Sashi, 2012). With Customer Engagement, a brand will focus on satisfying customers by providing them with more or superior value than competitors to build trust and commitment to long-term relationships (Setia et al., 2019). Customer Engagement has 3 pillars, namely Content Engagement, Media Engagement and Engagement Marketing Activities (Sherman and Smith, 2013). In order for brands to invite customers to engage and interact on social media, marketers must know what customers want from the brand (VanAuken, 2015). Dimensions and indicators of customer engagement (Yoong \& Lian, 2019) in the research are: (1) Enthusiasm: reflects the sense of excitement and interest of the customer (customer) in a brand; (2) Attention: Reflects the customer's attention (customer) to a brand.; (3) Absorption: reflects a pleasant condition for the customer (customer), is happy and really enjoys his role as a consumer of a brand that he does not realize that time has passed.; (4) Interaction: reflects the interactions that occur between customers (customers) with the company/brand and with other customers (customers); (5) Identification: Reflects the level of a sense of unity and a sense of belonging to a customer (customer) towards a brand/company.

\section{MATERIALS AND METHODS}

The research method used in this research is a quantitative approach, which means it is a means of testing objective theory by examining the relationship between variables. This research was conducted by analysing the influence of variable $X$, namely the social media content of Instagram @mrtjkt on variable $\mathrm{Y}$, namely the brand engagement of MRT Jakarta users. Quantitative research

Int'1 J. of Org. Bus. Excellence Vol. 3(2): 41 - 48 (2020) 
Safitri, Yulianne, Evelina, Lidya W. and Syahputra, Naufal E.

describes or explains a problem whose results can be generalized. Thus it does not place too much importance on the depth of data or analysis. Researchers are more concerned with the broad aspect of the data so that the data or research results are considered to be a representation of the entire population.

The population of the research is the number of followers of Instagram @mrtjkt recorded on April 1, 2020, which is $282 \mathrm{k}$ followers. With a research sample of 100 people based on the results of calculations using the Slovin formula. The number of questions in this research were 38 items on a Likert scale: 1 (Strongly disagree), 2 (disagree), 3 (neutral), 4 (Agree), 5 (strongly agree).

The quantitative analysis used in this research is correlation test, determination coefficient test, and simple regression analysis. The data validity technique for this study was tested for validity, reliability test and normality test. The hypothesis of this study is $\mathrm{HO}=$ There is no influence between social media branding via Instagram on MRT Jakarta customer engagement. and $\mathrm{H} 1=$ There is an influence between social media branding through Instagram on MRT Jakarta customer engagement.

\section{RESULTS AND DISCUSSIONS}

Based on the data from the validity test, the $r$ table value obtained through the Pearson product moment $r$ table, the result is 0.355 . From the results of the validity test on variable $X$, namely social media branding and variable $Y$, namely customer engagement, it can be seen that $r$ count $>r$ table in each statement, it can be concluded that all statements of variables $X$ and $Y$ are valid. The reliability test was carried out by measuring using cronbach's alpha, the results were 0.905 for variable $X$ and 0.952 for variable $Y$. Both variables are in the interval 0.81-1.00 on the Cronbach's alpha table, so it can be concluded that the two variables are very reliable, which means that the statements on variables $X$ and $Y$ in the questionnaire remain consistent even though they are repeated measurements. The normality test is carried out to determine whether the regression model residuals are normally distributed. A good regression model is normally distributed. The technique used in this study to test for normality is to use the Kolomogrov-Smirnov technique and the Probability Plot (P-Plot).

Table 1. Kolmogorov-Smirnov Test

$\begin{array}{lll} & & \begin{array}{l}\text { Unstandardized } \\ \text { Residual } \\ \mathrm{N}\end{array} \\ & \text { Mean } & 31 \\ \text { Normal } & \text { Std. } & 0.0000000 \\ \text { Parametersa,b } & \text { Deviation } & 930.246 .033 \\ & \text { Absolute } & 0.076 \\ \text { Most Extreme } & \text { Positive } & 0.076 \\ \text { Differences } & \text { Negative } & -0.072 \\ & & 0.076 \\ \text { Test Statistic } & & \mathbf{0 . 2 0 0 c , d ~} \\ \text { Asymp. Sig. (2-tailed) } & & \end{array}$

a Test distribution is Normal.

b Calculated from data.

c Lilliefors Significance Correction.

$d$ This is a lower bound of the true significance.

Based on the results of the normality test in Table 1, it is known that the sig value is 0.200 , which means that it is greater than 0.05 , which is normal data. It can be concluded that the data is normally distributed, which is one of the requirements for performing a simple linear regression analysis (Figure 2).

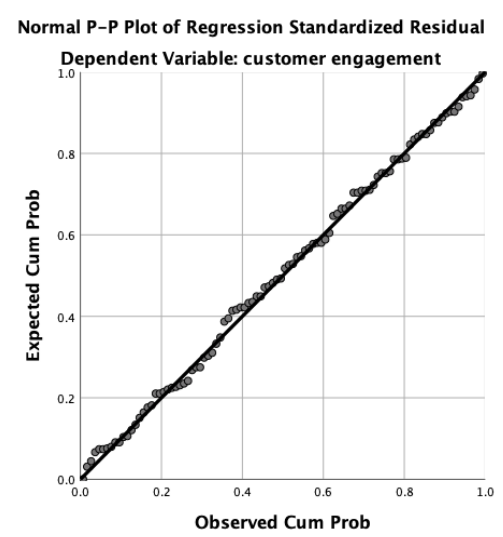

Figure 2. P-Plot

Correlation test is conducted to find out how strong the relationship between variables is expressed in the correlation coefficient ( $r)$. The results of the correlation test can be seen in Table 2 . 
Table 2. Correlations Test

\begin{tabular}{llll}
\hline & & $\begin{array}{l}\text { Social } \\
\text { media } \\
\text { branding }\end{array}$ & $\begin{array}{l}\text { Customer } \\
\text { engagement }\end{array}$ \\
$\begin{array}{llll}\text { social media } \\
\text { branding }\end{array}$ & $\begin{array}{l}\text { Pearson } \\
\text { Correlation }\end{array}$ & 1 & $0.776^{* *}$ \\
& $\begin{array}{l}\text { Sig. (2-tailed) } \\
\text { N }\end{array}$ & 100 & 0.000 \\
& $\begin{array}{l}\text { Pearson } \\
\text { Correlation }\end{array}$ & $0.776^{* *}$ & 100 \\
customer & Sig. (2-tailed) & 0.000 & \\
engagement & $\mathrm{N}$ & 100 & 100 \\
\hline ** Correlation is significant at the 0.01 level (2-tailed). & \\
& & &
\end{tabular}

Based on the results of the correlation test in the table above, it is known that the value in the table of the correlation coefficient of social media branding with customer engagement is 0.776 which is classified as a high or strong relationship. This means that the results of this study indicate that the use of social media branding has a strong influence on the formation of customer engagement.

The coefficient of determination test is needed to determine the ability of the independent variable to explain the dependent variation. The results of the coefficient of determination test is provided in Table 3 .

\section{Table 3. Coeficient of Determination Test}

\begin{tabular}{lllll}
\hline Model Summary & & & & \\
\hline & & $\mathrm{R}$ & Adjusted & $\begin{array}{l}\text { Std. Error } \\
\text { of the }\end{array}$ \\
Model & $\mathrm{R}$ & Square & $\mathrm{R}$ Square & Estimate \\
1 & $0.609 a$ & 0.371 & 0.365 & 10.711 \\
\hline a Predictors: (Constant), social media branding &
\end{tabular}

Based on the results of the determination coefficient test in the table above, it is known that the influence of variable $X$, namely social media branding through social media Instagram, on variable $\mathrm{Y}$, is customer engagement, which is $36.5 \%$, while the other $63.5 \%$ is influenced by other factors that are not present in the research.

Regression analysis is used to research whether there is a significant or not relationship or effect between these causes and effects. Hence this form of relationship is called regression. The results of the SPSS calculation for regression analysis are provided in Table 4.

Table 4. Regression Test

\begin{tabular}{|c|c|c|c|c|c|c|}
\hline \multicolumn{7}{|c|}{ Coefficients $^{a}$} \\
\hline \multirow{3}{*}{\multicolumn{2}{|c|}{ Model }} & \multirow{2}{*}{\multicolumn{2}{|c|}{$\begin{array}{l}\text { Unstandardized } \\
\text { Coefficients }\end{array}$}} & \multirow{3}{*}{$\begin{array}{l}\text { Standardized } \\
\text { Coefficients } \\
\text { Beta }\end{array}$} & \multirow[t]{3}{*}{$\mathrm{T}$} & \multirow[t]{3}{*}{ Sig. } \\
\hline & & & & & & \\
\hline & & B & $\begin{array}{l}\text { Std. } \\
\text { Error }\end{array}$ & & & \\
\hline \multirow[t]{2}{*}{1} & (Constant) & 14.431 & 7.090 & & 2.035 & 0.045 \\
\hline & $\begin{array}{l}\text { Socmed } \\
\text { Branding }\end{array}$ & 0.821 & 0.108 & 0.609 & 7.604 & 0.000 \\
\hline \multicolumn{6}{|c|}{ a. Dependent Variable: purchased intention } & \\
\hline
\end{tabular}

Based on the results of simple linear regression analysis in the Table 4 , it is known that the constant value is $(14,431)$ while the value of the $X$ variable, namely social media branding, is (0.609). This means that if there is no increase in the value of the social media branding variable $(X)$, then the value of the customer engagement variable $(Y)$ is $(14,431)$. Meanwhile, if the value of the social media branding variable $(X)$ is higher, it will increase the level of customer engagement. Vice versa, if the lower the level of social media branding used, it will reduce the level of customer engagement from MRT Jakarta. This $t$ / hypothesis test aims to determine the effect of social media branding through Instagram on customer engagement, with the following decision-making criteria: (1) If $t$ Count $<t$ Table then Ho is accepted (2) If $t$ Count $>t$ Table then Ho is rejected. Table 5 provides the results of the $t$ test calculation.

Table 5. Hypothesis Test

\begin{tabular}{|c|c|c|c|c|c|c|}
\hline \multicolumn{7}{|c|}{ Coefficients $^{a}$} \\
\hline \multirow{2}{*}{\multicolumn{2}{|c|}{ Model }} & \multicolumn{2}{|c|}{$\begin{array}{l}\text { Unstandardized } \\
\text { Coefficients }\end{array}$} & \multirow{2}{*}{$\begin{array}{l}\text { Standardized } \\
\text { Coefficients } \\
\text { Beta }\end{array}$} & \multirow[t]{2}{*}{$\mathrm{T}$} & \multirow[t]{2}{*}{ Sig. } \\
\hline & & B & $\begin{array}{l}\text { Std. } \\
\text { Error }\end{array}$ & & & \\
\hline \multirow[t]{2}{*}{1} & (Constant) & 14.431 & 7.090 & & 2.035 & 0.045 \\
\hline & $\begin{array}{l}\text { Socmed } \\
\text { Branding }\end{array}$ & 0.821 & 0.108 & 0.609 & 7.604 & 0.000 \\
\hline
\end{tabular}

From the results of the regression analysis table above, it is known that the $t$ count is 7,604 , then $7,604>1,984$ so that $\mathrm{Ho}$ is rejected. In conclusion, this data shows that the influence of social media branding through Instagram on MRT Jakarta customer engagement. 
Safitri, Yulianne, Evelina, Lidya W. and Syahputra, Naufal E.

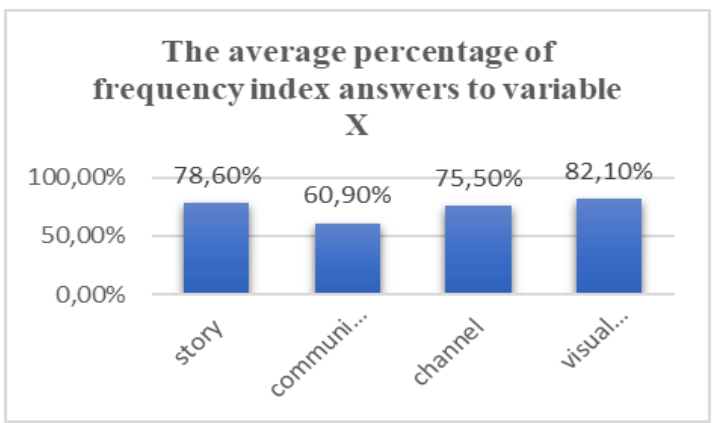

Figure 3. The average percentage of frequency index answers to variable $X$

Based on the results in Figure 3 on the respondents' answers, the $X$ Social Media Branding variable, the Visual Identity dimension consisting of logo indicators, icons and image visualizations that can reflect the brand, obtained the highest percentage average frequency index answer (Budiati, Grigolo, Brussel, \& Rachmat, 2018). Whereas in the $Y$ variable of customer engagement, the highest average frequency index percentage of answers is the enthusiasm dimension with indicators of pleasure and enthusiasm.

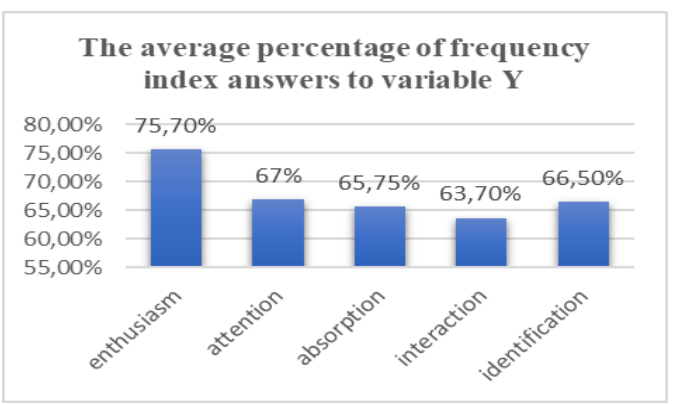

Figure 4. The average percentage of frequency index answers to variable $Y$

Based on results in Figure 4 regarding branding on Instagram social media, visual identity plays an important role in shaping enthusiasm in customer behavior. Instagram social media content in the form of videos, photos, logos, images or icons can affect the pleasure and enthusiasm of respondents so that a relationship between consumers and brands is created.

\section{CONCLUSIONS AND RECOMMENDATION}

Based on the results of research that has been done, namely "The Influence of Social Media Branding through Instagram on
Customer Engagement in MRT Jakarta" it can be concluded that:

a. Based on the correlation test, it can be stated that social media branding through Instagram has a relationship with MRT Jakarta customer engagement. The relationship between social media branding and MRT Jakarta customer engagement has a significance of 0.776 , so it shows a high/strong level of relationship.

b. Based on the results of the coefficient of determination test, it can be stated that social media branding through Instagram has an influence on MRT Jakarta customer engagement. The influence of social media branding on MRT Jakarta customer engagement has a value of $36.5 \%$. Meanwhile, the other $63.5 \%$ may be influenced by other factors not present in the research.

Other factors may be in the form of branding social media from other social media such as Twitter branding social media, Facebook branding social media, or even YouTube branding social media which can affect customer engagement from MRT Jakarta.

Another factor that follows is in the analysis table of the variable $Y$ customer engagement per dimension, it can be seen that the highest is the enthusiasm dimension, the dimension itself beats the interaction dimension, which in the indicator is the interaction between the customer and the company.

The conclusion is that the followers of the $@$ @rtjkt Instagram account are only excited when they see content from the @mrtjkt Instagram account or when they want to interact, but have not yet reached the stage of true followers - interacting with the company, for example followers are only excited when they see Instagram social media content @mrtjkt, but does not provide comments, likes, feedback, or messages.

It suggested that this research is developed with qualitative research to find out in more 
detail the reasons why people are not aware of the Jakarta MRT Transportation.

\section{REFERENCES}

Atmoko, B. D. (2012). Instagram Handbook. Jakarta: Media Kita.

Barger, V. P. (2016). Social media and consumer engagement: A review and research agenda. Journal of Research in Interactive Marketing, 10(4), 268-287. https://doi.org/10.1108/JRIM-06-20160065

Budiati, W., Grigolo, A., Brussel, M., \& Rachmat, S. (2018). Determining the potential for Transit Oriented Development along the MRT Jakarta corridor. The 1st ITB Centennial and 4th PlanoCosmo International Conference. 158, pp. 1-15. Bandung: IOP.

Chasanah, R. and Wijaya, A. (2020). The analysis of service quality using importance performance anaysis for MRT Jakarta. Primanomics: Jurnal Ekonomi dan Bisnis, 18(1), 1-10. https://doi.org/10.31253/pe.v18i3.397

Diamond, S. (2013). The Visual Marketing Revolution: 26 Rules to Help Social Media Marketer Connect the Dots. USA: Person.

Hootsuite (We are Social): Indonesia Digital Report 2019. (2019). Andilink. Retrieved on 26 September 2019 from https://hootsuite-we-are-socialindonesian-digital report-2019/

Jakarta MRT. (n.d.). Visi dan Misi. Retrieved on October 2020, from Jakarta MRT: https://www.jakartamrt.co.id/mrtjakarta/visi-misi/

Jokinen, T. (2016). Branding in social media and the impact of social media on brand image. (Thesis). School of Business and Culture International Business, Seinajoki University of Applied Sciences, Southern Ostrobothnia.

https://www.theseus.fi/bitstream/handl e/10024/105658/Jokinen Tomi.pdf?sequ ence $=1$

Kemal, M. and Ernungtyas, N. (2020). Pengaruh kampanye \#UbahJakarta oleh PT MRT Jakarta terhadap Niat Menggunakan
Transportasi Publik di Jakarta. Jurnal Cakrawala, 20(1), 51-62. https://doi.org/10.31294/jc.v20i1.7733 Kompella, K. (2014). The Definitive Book of Branding. India: Sage Publication.

Kriyantono, R. (2014). Teknik Praktis Riset Komunikasi. Jakarta: Prenada Media.

Moens, M. F., Li, J. and Chua, T. S. (2014). Mining User Generated Content. London: CRC Press.

Nasrullah, R. (2015). Media Sosial Perspektif Komunikasi, Budaya dan Sosioteknologi. Bandung: Simbiosa Rekatama Media.

Nurcahyo, R., Iqbal, V. and Habiburrahman, M. (2020). Inventory calculation for ticket card of PT MRT Jakarta. International Symposium on Advances in Mechanical Engineering (pp. 040003-1-040003-6). AIP Conference Proceedings.

Ramkumar, R., Kumar, A., Janakiraman, R. and Bezawada, R. (2013). The effect customer's social media participation on customer visit frequency and profitablility: An empirical investigation. Information System Research, 24(1), 108127.

https://doi.org/10.1287/isre.1120.0460

Rowles, D. (2014). Digital Branding: A Complete Step-by-Step Guide to Strategy, Tactics and Measurement. UK: Kogan Publisher.

Sashi, C. (2012). Customer engagement, buyerseller relationships, and social media. Journal Management Decision, 50(2), 253-272.

https://doi.org/10.1108/0025174121120 $\underline{3551}$

Setia, N. R., Nelwa, R. F., Marina, S. and Hidayat, M. (2019). SWOT analysis in MRT Jakarta. Advances on Transportation and Logisctics Research, 2, 504-515). https://proceedings.itltrisakti.ac.id/index .php/ATLR/article/view/204/235

Sherman, A. and Smith, D. E. (2013). Social Media Engagement for Dummies. Canada: John Wiley \& Sons, Inc.

VanAuken, K. (2015). Using social media to improve customer engagement and promote products and services. Journal of Airport Management, 9(2), 109-117.

Int'1 J. of Org. Bus. Excellence Vol. 3(2): 41 - 48 (2020) 
Safitri, Yulianne, Evelina, Lidya W. and Syahputra, Naufal E.

https://www.henrystewartpublications.c om/sites/default/files/VanAuken.pdf

Yoong, L. C. and Lian, S. B. (2019). Customer Engagement in Social Media and Purchase Intention in The Hotel Industri. Internation Journal of Academic Research in Business \& Social Sciences, 9(1). 